\title{
Large Plankton Enhance Heterotrophy Under Experimental Warming in a Temperate Coastal Ecosystem
}

\author{
Tamara Megan Huete-Stauffer, ${ }^{1,2}$ * ( Nestor Arandia-Gorostidi, ${ }^{2}$ \\ Natalia González-Benítez, ${ }^{3}$ Laura Díaz-Pérez, ${ }^{2}$ Alejandra Calvo-Díaz, ${ }^{2}$ and \\ Xosé Anxelu G. Morán ${ }^{1}$
}

\begin{abstract}
${ }^{1}$ Red Sea Research Center, Division of Biological and Environmental Sciences and Engineering, King Abdullah University of Science and Technology, Thuwal 23955-6900, Saudi Arabia; ${ }^{2}$ Centro Oceanográfico de Gijón/Xixón, Instituto Español de Oceanografía, 33212 Gijón/Xixón, Spain; ${ }^{3}$ Department of Biology and Geology, Rey Juan Carlos University, 28933 Madrid, Spain
\end{abstract}

\begin{abstract}
Microbes are key players in oceanic carbon fluxes. Temperate ecosystems are seasonally variable and thus suitable for testing the effect of warming on microbial carbon fluxes at contrasting oceanographic conditions. In four experiments conducted in February, April, August and October 2013 in coastal NE Atlantic waters, we monitored microbial plankton stocks and daily rates of primary production, bacterial heterotrophic production and respiration at in situ temperature and at 2 and $4^{\circ} \mathrm{C}$ over ambient values during 4-day incubations.
\end{abstract}

Received 17 June 2017; accepted 21 November 2017; published online 15 December 2017

Electronic supplementary material: The online version of this article (https://doi.org/10.1007/s10021-017-0208-y) contains supplementary material, which is available to authorized users.

Authors Contributions All authors (TMHS, NAG, NG, LDP, ACD and XAGM) contributed to the data acquisition during experiments and to the revision of the manuscript. In addition, XAGM designed the experiment and TMHS analyzed the data and wrote the manuscript.

*Corresponding author; e-mail: tamara.huete@gmail.com
Ambient total primary production (TPP) exceeded total community respiration $(<200 \mu \mathrm{m}, \mathrm{TR})$ in winter and fall but not in spring and summer. The bacterial contribution to ecosystem carbon fluxes was low, with bacterial production representing on average $6.9 \pm 3.2 \%$ of TPP and bacterial respiration (between 0.8 and $0.2 \mu \mathrm{m}$ ) contributing on average $35 \pm 7 \%$ to TR. Warming did not result in a uniform increase in the variables considered, and most significant effects were found only for the $4^{\circ} \mathrm{C}$ increase. In the summer and fall experiments, under warm and nutrient-deficient conditions, the net TPP/TR ratio decreased by 39 and $34 \%$ in the $4^{\circ} \mathrm{C}$ treatment, mainly due to the increase in respiration of large organisms rather than bacteria. Our results indicate that the interaction of temperature and substrate availability in determining microbial carbon fluxes has a strong seasonal component in temperate planktonic ecosystems, with temperature having a more pronounced effect and generating a shift toward net heterotrophy under more oligotrophic conditions as found in summer and early fall.

Key words: carbon flux; global warming; microbial plankton; NE Atlantic; metabolic balance; coastal ocean. 


\section{INTRODUCTION}

Half of the primary production of the planet takes place in the upper lit ocean (Field and others 1998), with a large fraction being cycled through the dissolved organic matter (DOM) pool and metabolized by bacteria (Ducklow and others 2010). Microbes play key roles in all biogeochemical cycles (Azam 1998; Jorgensen 2000; Azam and Malfatti 2007; Fuhrman 2009), and more specifically, microbial photosynthesis, secondary production and respiration are key to determine the carbon balance of the oceans (that is, the balance between fixed and respired carbon; Bauer and others 2013; Ducklow and Doney 2013) and the efficiency of the microbial carbon pump (Stone 2010). All of these ecological processes are highly dependent on temperature (López-Urrutia and others 2006) which justifies the great efforts developed into predicting the responses of phytoplankton and heterotrophic organisms (Doney 2006; López-Urrutia and others 2006; Behrenfeld 2011; YvonDurocher and others 2012; Ducklow and Doney 2013) to the expected temperature rises in the current century (Collins and others 2013).

Uncertainty in the response of microbial carbon fluxes to warming emerges because although metabolism is enhanced by temperature, and consequently, microbial rates are predicted to increase with warming (Brown and others 2004), not all processes have the same temperature dependence (Allen and others 2005; López-Urrutia and others 2006) and temperature is not the only factor driving metabolism, with for example, light (mostly for phytoplankton) and resource availability (for bacteria, phytoplankton and other microbes) also playing crucial roles (Doney 2006; López-Urrutia and others 2006; Behrenfeld 2011).

According to the metabolic theory of ecology (MTE, sensu Brown and others 2004), heterotrophic processes (for example, respiration) have a greater temperature dependence than autotrophic processes (photosynthesis), with mean activation energies of 0.65 and $0.32 \mathrm{eV}$, respectively. A direct consequence of global warming would thus be a shift toward heterotrophy in the future ocean and a reduction in overall $\mathrm{CO}_{2}$ fixation (modeled as a $21 \%$ decrease in the next century by López-Urrutia and others 2006). The MTE is based on the premises that individual metabolism increases exponentially with temperature and as a power law of mass (West and others 1999; Gillooly and others 2001). However, besides temperature and size, other factors (light and nutrient availability as sta- ted above, but also DOM quality, community composition, grazing pressure, and so on) may rise at stages as important as temperature in shaping planktonic communities and buffer the expected metabolic response. For example, in Huete-Stauffer and others (2015) we observed in heterotrophic bacteria from a temperate coastal site that the activation energies of specific growth rates were not constant, but followed a seasonal cycle according to stratification and mixing periods and that the expected value of $0.65 \mathrm{eV}$ was only approached during spring. This example shows that the metabolism of planktonic organisms may be intimately linked to underlying oceanic processes affecting inorganic nutrients, DOM and light availability. Therefore, the overall metabolic state of the oceans (autotrophic or heterotrophic) may not be accurately estimated assuming a unique activation energy value for autotrophs and heterotrophs.

It is true, however, that most warming experiments have shown shifts toward a prevalence of heterotrophic over autotrophic processes within the microbial community. For example, mesocosm experiments in the Baltic have shown an increase in the coupling of heterotrophic bacterial activity to phytoplankton (measured as the ratio between bacterial production to particulate primary production, BP/PPP), increased bacterial respiration (BR), reductions in the lag phase between the end of the phytoplankton bloom and start of bacterial degradation of DOM (Hoppe and others 2008) and decreases in the export of biogenic carbon associated with increased bacterial activity (Wohlers and others 2009). O'Connor and others (2009) in the eastern Pacific observed shifts in the community structure with increases in the heterotrophic-to-autotrophic biomass ratio, which especially increased in nutrient amended incubations. Vázquez-Domínguez and others (2007) observed paired increases in time series data of BP and BR in the NW Mediterranean, whereas Kritzberg and others (2010) found that increases in BR were much larger than in BP in the Arctic in 2-day incubations. In contrast, in the tropics, Pires and others (2014) found that BR decreased with increasing temperatures, associated with the fact that bacteria were very close to their thermal upper tolerance limit.

The aforementioned examples, conducted in different oceanic regions, do not show a unique response and therefore support the idea that it is the interaction with other factors that determines the actual responses of planktonic microbial com- 
munities to warming (Lewandowska and others 2014). Many studies have been conducted in polar and subpolar waters since the temperature dependences of organisms were shown to be higher than in temperate areas (Pomeroy and Wiebe 2001) and the effects of global warming are expected to be more drastic there (Sarmiento and others 2004; Behrenfeld and others 2006). However, although temperate and subtropical areas represent a much greater area of the ocean's surface, they are somewhat underrepresented in experimental warming studies.

In this study, we analyzed the effects of temperature on key microbial carbon fluxes (primary production, bacterial production and community and bacteria respiration rates) in surface waters of a coastal temperate site in the southern Bay of Biscay. It is rare that bacterial production, partitioning of phytoplanktonic organic carbon production (dissolved and particulate) and sizefractionated respiration are measured simultaneously in marine planktonic ecosystems together with their responses to experimental warming. According to the MTE predictions as explained above, a switch toward net heterotrophy would be expected at higher temperatures, even in a currently balanced ecosystem as the Bay of Biscay (oxygen production equaling consumption over an annual scale; Serret and others 1999, 2001). To test this hypothesis, we incubated natural samples at three different temperatures (in situ, +2 and $+4^{\circ} \mathrm{C}$ ) on four different occasions representing the variable oceanographic conditions found during the year at this site (winter mixing, spring bloom, summer stratification and fall). The study of the response to warming under different combinations of nutrient availability and temperature at each of these periods helped us further understand the regulation of microbial carbon cycling and its possible response to future warming.

\section{Materials ANd Methods}

\section{Sampling Site and Experimental Design}

Samples were taken at $5 \mathrm{~m}$ from a $110 \mathrm{~m}$ deep station $\left(43.675^{\circ} \mathrm{N}, 5.578^{\circ} \mathrm{W}\right), 15.7 \mathrm{~km}$ off Gijón/ Xixón (Spain) on the continental slope of the southern Bay of Biscay, on 4 occasions during 2013 (Table 1). Water for all variables and incubations was sampled from 5-L Niskin bottles mounted on a 25-bottle rosette attached to a Sea-Bird CTD probe. A temperature stratification index (SI) was calculated as the difference between the surface and bottom temperatures. We considered that the water column was stratified when SI was greater than $0.5^{\circ} \mathrm{C}$ (Monterey and Levitus 1997; de Boyer Montégut and others 2004). As well, the upper mixed layer was determined from the potential density gradient, as the shallowest depth where the potential density showed a difference in $0.05 \mathrm{~kg} \mathrm{~m}^{-3}$ in a $5 \mathrm{~m}$ range (Calvo-Díaz and others 2011; Franco-Vidal and Morán 2011). Nutrients (nitrate and phosphate) were determined as part of the routine sampling of the RADIALES time series as explained in Calvo-Díaz and Morán (2006). Water used for the incubations was filtered through a 200- $\mu \mathrm{m}$ mesh in order to remove large plankton and used to fill 9 acid-washed 10-L polycarbonate Nalgene bottles that were stored in the dark until reaching the laboratory, approximately within $4 \mathrm{~h}$. Three bottles were placed per temperature treatment inside incubators set at the in situ temperature and +2 and $+4^{\circ} \mathrm{C}$ over in situ values. Each bottle was manually agitated every $6-12 \mathrm{~h}$ and was sampled daily for size-fractionated chlorophyll $a$, primary production partitioning, bacterial abundance, bacterial production and community and bacterial respiration. Details of each procedure are detailed below. Incubations lasted from 3 to 5 days, until bacterial abundances had begun to decay. Temperature was monitored inside the incubation bottles using an automatic logger (Thermotrack,

Table 1. Study Site Conditions at the Initial Sampling Times

\begin{tabular}{lllllllllll}
\hline 2013 & Temp & Sal & SI & $\mathrm{NO}_{3}$ & $\mathrm{PO}_{4}$ & PAR & Photoperiod & Chl $a$ & Bac Ab & eCF \\
\hline February 2 & 12.6 & 34.8 & 0.13 & 4.72 & 0.16 & 60.2 & 10.5 & 2.69 & $1.11 \times 10^{6}$ & 2.34 \\
April 15 & 13.8 & 34.6 & 0.31 & 3.23 & 0.17 & 307.6 & 13.4 & 2.95 & $1.36 \times 10^{6}$ & 3.54 \\
August 29 & 20.3 & 35.5 & 5.38 & 0.18 & 0.02 & 304.5 & 13.1 & 0.53 & $1.15 \times 10^{6}$ & 2.53 \\
October 6 & 19.1 & 35.4 & 2.87 & 0.19 & 0.02 & 58.5 & 10.9 & 0.94 & $1.14 \times 10^{6}$ & 0.90
\end{tabular}

Temp surface temperature $\left({ }^{\circ} \mathrm{C}\right)$, Sal salinity, SI stratification index $\left({ }^{\circ} \mathrm{C}\right), \mathrm{NO}_{3}$ nitrate concentration $\left(\mu m o l L^{-1}\right)$, PO $\mathrm{P}_{4}$ phosphate concentration $\left(\mu m o l\right.$ L $\left.L^{-1}\right)$, PAR photosynthetically active radiation ( $\mu$ mol photons $m^{-2} s^{-1}$ ), Photoperiod $(h)$, Chl a chlorophyll a $\left(\mu g L^{-1}\right)$, Bac Ab bacterial abundance (cells $m L^{-1}$ ) from HNA + LNA groups, eCF

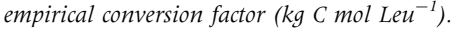


Progress Plus) placed inside a separate bottle filled with water and programmed to measure temperature every hour. Light (photosynthetically active radiation, PAR) measurements inside the incubators averaged $267 \pm 5 \mu \mathrm{mol}$ photons $\mathrm{m}^{-2} \mathrm{~s}^{-1}$, which was saturating for photosynthesis (according to Morán 2007), and light-dark cycles were set to mimic the photoperiod of the sampling day (Table 1).

\section{Size-Fractionated Chlorophyll $a$}

Samples for chlorophyll $a$ determination $(50 \mathrm{~mL}$ ) were filtered daily through three consecutive polycarbonate 25 -mm-diameter filters $(20,2$ and $0.2 \mu \mathrm{m}$ pore sizes) to separate micro-, nano- and picophytoplankton size classes, respectively. Each filter was collected in a separate vial and frozen at $-20^{\circ} \mathrm{C}$ until pigment extraction. This was done overnight in $90 \%$ acetone, and extracts were read in a LS-55 spectrofluorometer (PerkinElmer) as explained in more detail in Calvo-Díaz and Morán (2006).

\section{Bacterial Standing Stocks}

Three physiological groups of bacteria were analyzed twice a day with a BD FACSCalibur flow cytometer equipped with an argon $488 \mathrm{~nm}$ laser. The group of Live cells represented cells with intact membranes, that is, cells only stained with the nucleic acid dye SYBR Green I (Molecular Probes), after double staining with SYBR Green I and propidium iodide (Sigma-Aldrich). In contrast, membrane-compromised or Dead cells appeared stained with propidium iodide (Grégori and others 2001; Falcioni and others 2008) and were not considered further in this study. The groups of high and low nucleic acid content bacteria (HNA and LNA, respectively) represented subgroups separated according to their relative fluorescence after staining with SYBR Green I (Marie and others 1997). Live versus Dead cell samples were analyzed in vivo, whereas the samples for HNA and LNA cells were fixed with a final concentration of $1 \%$ paraformaldehyde and $0.05 \%$ glutaraldehyde and frozen at $-80^{\circ} \mathrm{C}$ until analysis. All groups of bacteria were analyzed using a low flow rate (approx. 15-20 $\mu \mathrm{L} \mathrm{min}{ }^{-1}$ ) during $2 \mathrm{~min}$ or until 10,000 counts were achieved. $1-\mu \mathrm{m}$ fluorescent latex beads (Molecular Probes) were added to all samples as a standard for size and fluorescence. The abundances and the relative size and fluorescence were obtained by gating the bacterial populations using Paint-A-Gate software (BD Biosciences).
The abundance and cell size of HNA and LNA bacteria were used to calculate the biomass needed for obtaining empirical conversion factors for BP (detailed below). The conversion of the flow cytometric side scatter signal to bacterial volume was done using the empirical calibration in Calvo-Díaz and Morán (2006) and assuming a spherical shape of all bacteria. Biovolume to carbon mass transformation was made using the equation of Norland (1993).

\section{Primary Production}

Primary production was partitioned between two fractions, particulate (PPP, between 200 and $0.22 \mu \mathrm{m}$ ) and dissolved (DPP, below $0.22 \mu \mathrm{m}$ ). Primary production rates were estimated at the beginning of the experiments (time 0 ) and then daily during the first 3 days of the incubations, except in February, in which determinations were made on days 1, 3 and 5 . Each day, triplicate $70 \mathrm{~mL}$ subsamples were extracted from each 10-L Nalgene bottle at the onset of daylight, placed in sterile polystyrene tissue culture flasks (Iwaki) and spiked with $10 \mu \mathrm{Ci}\left(3.710^{5} \mathrm{~Bq}\right){ }^{14} \mathrm{C}$-bicarbonate. Two light plus one dark (covered with aluminum foil) flasks were incubated under constant saturating PAR irradiance (ca. $200 \mu \mathrm{mol}$ photons $\mathrm{m}^{-2} \mathrm{~s}^{-1}$ ) at the three temperature treatments for ca. $2 \mathrm{~h}$. After this time, $5 \mathrm{~mL}$ was filtered through $0.22-\mu \mathrm{m}$ mixed cellulose esters membrane filters (Millipore) and the filtrate was collected for determining dissolved organic carbon $\left(\mathrm{DO}^{14} \mathrm{C}\right)$ production (DPP). $60 \mathrm{~mL}$ was filtered through another filter of the same type, which was collected for determining particulate organic carbon $\left(\mathrm{PO}^{14} \mathrm{C}\right)$ production (PPP). More details about the elimination of inorganic ${ }^{14} \mathrm{C}$ in the liquid subsamples and in the filters are given in Morán and others (2006). After addition of Ultima Gold XR (PerkinElmer) liquid scintillation cocktail ( $15 \mathrm{~mL}$ to the liquid samples and $5 \mathrm{~mL}$ to the filters, in 20 and $6 \mathrm{~mL}$ plastic vials, respectively), disintegrations per minute $(\mathrm{dpm})$ were measured in a PerkinElmer TriCarb 2800 TR liquid scintillation counter. At this point, the dpm values of the dark flask were subtracted from the light flasks, to correct for any non-photosynthetic uptake of carbon. We used a dissolved inorganic carbon concentration of $25,000 \mathrm{mg} \mathrm{m}^{-3}$ for converting dpm to carbon units. Empirical determinations in the study area over 1 year showed values ranging from 25,000 to $26,000 \mathrm{mg} \mathrm{m}^{-3}$ (Franco-Vidal and others unpubl.). Hereinafter, we will use the sum of PPP and DPP as total primary production (TPP). Daily rates were calculated multiplying the hourly rates 
by daylight hours. The percent extracellular release (PER) was calculated as DPP/TPP* 100 .

\section{Bacterial Production}

Bacterial production was estimated using the incorporation rate of ${ }^{3} \mathrm{H}$-leucine following the protocols described in Kirchman and others (1985) and modified by Smith and Azam (1992), with further details provided in Franco-Vidal and Morán (2011). Briefly, $50 \mathrm{~mL}$ of water were taken from each of the triplicate 10-L bottles at the same time as for the primary production determinations. $4 \times 1 \mathrm{~mL}$ subsamples (including 1 control killed with $50 \%$ trichloroacetic acid: TCA) were placed into Eppendorf tubes and inoculated with a saturating concentration of $40 \mathrm{nmol} \mathrm{L}^{-1}{ }^{3} \mathrm{H}$-Leucine (Calvo-Díaz and Morán 2009; Franco-Vidal and Morán 2011). Samples were incubated in the light in the three different temperature incubators and stopped by the addition of $100 \mu \mathrm{L}$ of TCA $(50 \%)$ after about $2 \mathrm{~h}$. Samples were centrifuged twice in a refrigerated microcentrifuge for $10 \mathrm{~min}$ at $12,800 \times 9$, and the pellet was retained after aspiring the supernatant. Radioactivity (dpm) was counted in a PerkinElmer TriCarb 2800 TR liquid scintillation counter after adding $1 \mathrm{~mL}$ of liquid scintillation cocktail (Ultima Gold XR, PerkinElmer) to each vial.

To convert leucine incorporation rates $\left(\mathrm{pmol} \mathrm{L}^{-1}\right.$ $\mathrm{h}^{-1}$ ) into carbon biomass production rates, empirical conversion factors (eCFs) were determined for each of the four experiments using a modification of the cumulative method (Bjørnsen and Kuparinen 1991) as explained in detail in Calvo-Díaz and Morán (2009) but using the same measurements of the samples instead of separate incubations (non diluted and in light). eCFs were approximated by calculating the slope of the linear regression of a plot of cumulative leucine incorporation against heterotrophic bacterial biomass (sum of HNA and LNA bacterial biomass), during the first 2 days of the experiment, during the exponential phase, and

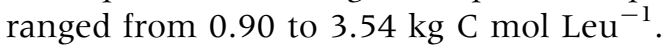

\section{Respiration}

We estimated respiration as the electron transport system (ETS) activity in vivo, using the 2-(4-iodophenyl)-3-(4-nitrophenyl)-5-phenyl-2H-tetrazolium chloride (INT) method. The ETS enzymatic chain involves dehydrogenase enzymes and cytochrome electron carrier proteins for electron transfer. With this method, the water-soluble INT penetrates the cells and, by the action of the ETS dehydrogenase enzymes, forms insoluble formazan crystals that can be analyzed by spectrophotometry (MartínezGarcía and others 2009). We selected this method in order to avoid the large volumes and long incubation times needed for the usual Winkler method and to avoid pre-filtration of samples in small fractions $(\sim 0.8-3 \mu \mathrm{m})$ that could substantially alter the respiration measurements (Aranguren-Gassis and others 2012). We followed the protocol of Martínez-García and others (2009). For each sampling time and experimental bottle, four replicate $125-\mathrm{mL}$ dark polycarbonate bottles were filled with $100 \mathrm{~mL}$ of each incubation treatment. One bottle was immediately fixed with $2 \%$ paraformaldehyde (final concentration) to serve as a killed control, and 30 min later all bottles were spiked with $0.2 \mathrm{mmol} \mathrm{L}^{-1}$ of INT (final concentration). After $1 \mathrm{~h}$ of incubation, all samples except the controls were fixed with $2 \%$ paraformaldehyde and stored at $4{ }^{\circ} \mathrm{C}$ until filtration $(2-3 \mathrm{~h})$, which was done sequentially through 0.8 and $0.2-\mu \mathrm{m}$ Whatman polycarbonate filters (47 $\mathrm{mm}$ diameter). Filters were placed into 2-mL cryovials and frozen at $-20^{\circ} \mathrm{C}$ until further processing. For extraction, $1.5 \mathrm{~mL}$ of isopropanol was added to the cryovials, which were then sonicated in a water bath for $30 \mathrm{~min}$ at $50^{\circ} \mathrm{C}$ and $40 \mathrm{kHz}$ (PowerSonic405, Hwashi Tech Co.) and shaken with a vortex before transferring the isopropanol volume into $1.5-\mathrm{mL}$ microcentrifuge tubes and centrifuging for $10 \mathrm{~min}$ at $12,800 \times g$ at $20^{\circ} \mathrm{C}$. Finally, the absorbance at $485 \mathrm{~nm}$ of each sample was measured using a spectrophotometer (Shimadzu UV-1603). Due to light sensitivity, all steps were performed in the dark. To transform the $485 \mathrm{~nm}$ absorbance to oxygen values, we first performed a calibration curve with known concentrations of INT-formazan $\left(\mu \mathrm{mol} \mathrm{L}{ }^{-1}\right)$ and applied it to convert the sample absorbance to units of INT-formazan $\left(\mu \mathrm{mol} \mathrm{L}^{-1}\right)$. We obtained the respiration rate in INT $\mu \mathrm{mol} \mathrm{L}^{-1}$ $\mathrm{h}^{-1}$ accounting for sample volume, extraction volume and incubation time (Supplementary Figure S1). These values were then transformed into oxygen units using the calibration extracted from Martínez-García and others (2009) (Supplementary Figure S1). Finally, to convert oxygen into carbon we considered a 1:1 stoichiometry (Robinson 2008) and we converted $\mu \mathrm{mol} \mathrm{L}^{-1} \mathrm{C} \mathrm{h}^{-1}$ to $\mu \mathrm{g} \mathrm{C} \mathrm{L}^{-1}$ day $^{-1}$, assuming that respiration was equal in the light and the dark.

For each sampling time, we obtained the respiration in two fractions: between 0.2 and $0.8 \mu \mathrm{m}$, which we will refer to as bacterial respiration (BR), and above $0.8 \mu \mathrm{m}(0.8-200 \mu \mathrm{m})$, thus including all larger plankton, represented hereinafter as $+0.8 \mathrm{R}$. The sum of both fractions represents total com- 
munity respiration $(<200 \mu \mathrm{m})$ (TR). Besides heterotrophic bacteria, BR may have included also a few cyanobacterial cells from the genera Synechococcus and Prochlorococcus, especially of the latter. However, heterotrophic cells are the major contributors of the $0.2-0.8 \mu \mathrm{m}$ size fraction, representing on average $85 \%$ of the total annual bacterial biomass (heterotrophic bacteria plus cyanobacteria) (Calvo-Díaz and Morán 2006).

\section{Microbial Community Interactions}

The simultaneous measurements of the rates of primary production (DPP and PPP), heterotrophic bacterial production (BP) and size-fractionated respiration (BR, $+0.8 \mathrm{R}$ and $\mathrm{TR}$ ) allowed us to investigate the carbon flowing through the microbial food web and the relative contribution of bacteria to the system. The bacterial carbon demand $(\mathrm{BCD}=\mathrm{BP}+\mathrm{BR})$, or gross bacterial production (Ducklow 2000), represented the total amount of carbon that bacteria needed to fuel their metabolism, allocating it to biomass production (BP) or respiration (BR). By knowing the $\mathrm{BCD}$, the bacterial growth efficiency $(\mathrm{BGE}=\mathrm{BP} / \mathrm{BCD})$ could be calculated as well, which indicated the proportion of biomass generated per unit of assimilated carbon considering the losses generated from respiration (del Giorgio and Cole 1998). It can be viewed also as the proportion of carbon taken up by bacteria that could be transferred to higher trophic levels. The values of BCD/DPP were used to infer the importance of phytoplankton for bacterial metabolism as a source of DOM (Morán and others 2001; Lomas and others 2002). In addition, we calculated the net community production (NCP), defined as the balance between fixed and respired carbon considering here the $<200 \mu \mathrm{m}$ planktonic community. The calculation of NCP has been traditionally derived from the Winkler method and is considered as the difference between oxygen production in the light (gross primary production, GPP) and oxygen consumption in the dark (dark respiration, DR) or NCP = GPP - DR (López-Urrutia and others 2006; Ducklow and Doney 2013). We assumed that DR was equivalent to our TR estimates, since it followed the same principle as DR (obtained in the dark and included the whole community). In turn, GPP was approximated by TPP. It is still debated whether the ${ }^{14} \mathrm{C}$ method represents a value closer to gross (Dring and Jewson 1982) or net primary production (Marra 2002, 2009). However, we assumed that TPP values were closer to GPP values since González and others (2008) concluded in a comparative study with other methods that if incubations are short (typically below $3 \mathrm{~h}$, but up to $12 \mathrm{~h}$ ), and if both the particulate and dissolved fractions are considered, TPP values are in good agreement with GPP values. Finally, the TPP/TR ratio was used to assess the relationship between autotrophic and heterotrophic metabolisms of the planktonic community $(<200 \mu \mathrm{m})$.

\section{Statistical Analysis}

Warming effects were analyzed as the differences between the in situ, +2 and $+4^{\circ} \mathrm{C}$ treatments for the following variables: total primary production (TPP), particulate primary production (PPP), dissolved primary production (DPP), percent extracellular release (PER), bacterial production (BP), bacterial respiration (BR), respiration of the $>0.8 \mu \mathrm{m}$ fraction $(+0.8 \mathrm{R})$ and total respiration (that is, the sum of both fractions, TR). The effect of temperature was analyzed using generalized additive mixed-effects models (GAMM) from the $\mathrm{R}$ package mgcv (Wood 2004) following the steps in Zuur and others (2009). The model was run separately for each of the four periods since differences between months were not the scope of the study and made the model more complex without justification. The GAMM type of model combines a linear mixed-effects model (LME, because we had fixed and random variables) and a generalized additive model (GAM, because the response variables were not linear). For the LME section, the model used temperature treatment as the fixed component and the individual replicates as the random component, which in turn were nested to the temperature treatment. For the GAM section, sampling time was used to model a nonlinear smoothed fit of the response variable. Autocorrelation between samples due to temporal repetition was accounted for in the model using an auto-regressive model of order 1 (where the residual time $t$ was modeled as a function of time $t-1$ ).

\section{Results}

A summary of the physicochemical conditions and biological variables at the start of the four experiments in 2013 is shown in Table 1. Surface temperatures in February and April were both close to the annual minimum $\left(\sim 12.5^{\circ} \mathrm{C}\right)$, whereas October values were unusually high and comparable to August. February and April were characterized by temperature homogeneous water columns (SI $<0.5^{\circ} \mathrm{C}$ ), but the presence of fresher water at the surface resulted in shallow upper mixed layers. 

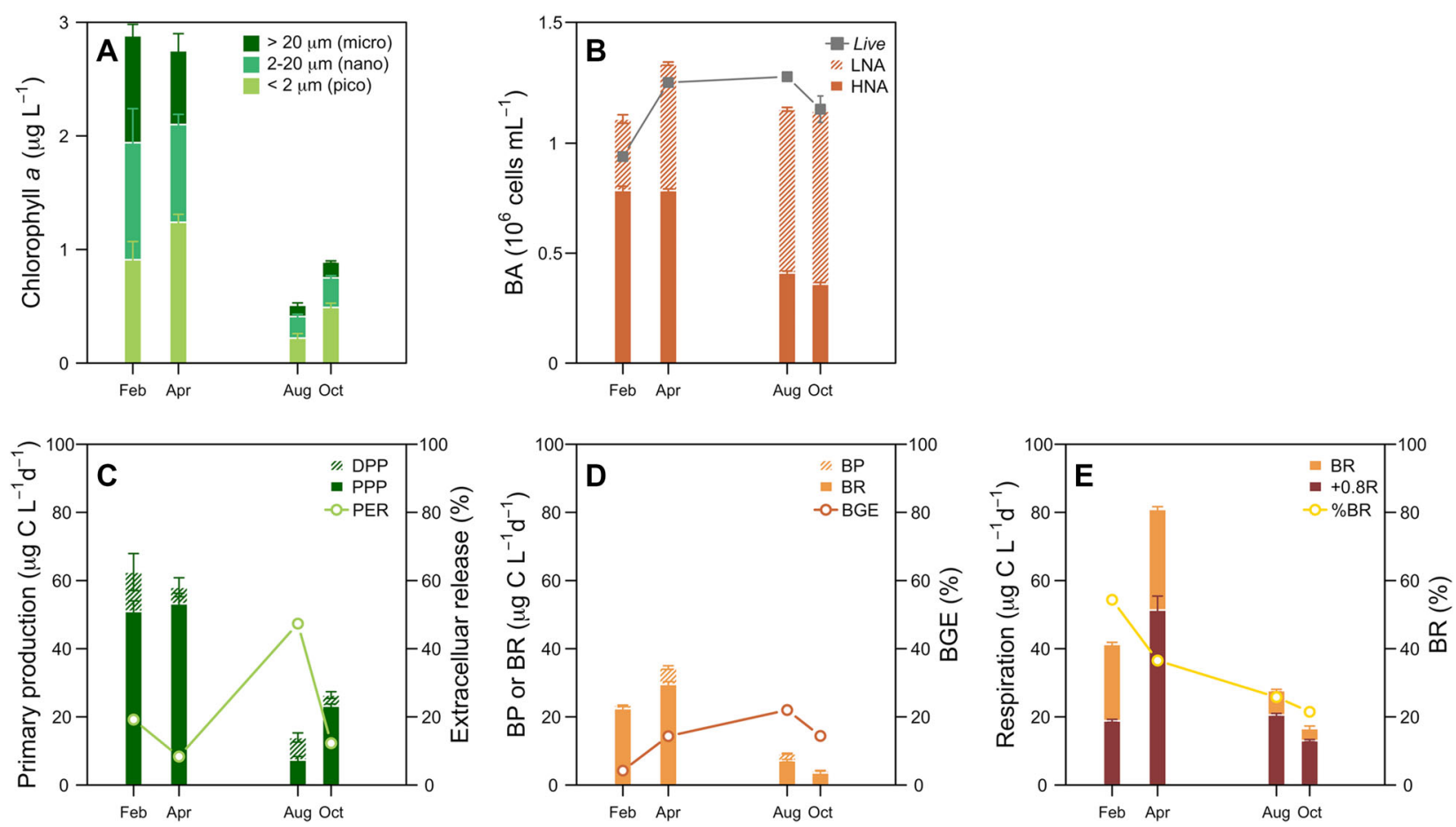

Figure 1. Ambient values of selected variables at each experiment: size-fractionated chlorophyll $a$ concentration (A); abundance of single-cell physiological bacterial groups $(\mathbf{B})$; primary production rates $(\mathbf{C})$ including PPP, DPP, PER and TPP $(\mathrm{PPP}+\mathrm{DPP})$; bacterial rates $(\mathbf{D})$ including $\mathrm{BP}, \mathrm{BR}, \mathrm{BGE}$ and $\mathrm{BCD}(\mathrm{BP}+\mathrm{BR})$; size-fractionated respiration rates $(\mathbf{E})$ including $\mathrm{BR},+0.8 \mathrm{R}, \% \mathrm{BR}$ and $\mathrm{TR}(\mathrm{BR}+0.8 \mathrm{R})$.

In August, the water column was strongly stratified with an upper mixed layer of $25 \mathrm{~m}$, which became more eroded in October, although still characterized by relatively high stratification $\left(\mathrm{SI}=2 \cdot 87^{\circ} \mathrm{C}\right)$. Consequently, inorganic nutrient concentrations were similarly high in the first two experiments, with over $3 \mu \mathrm{mol} \mathrm{L}{ }^{-1}$ of nitrate and approximately $0.2 \mu \mathrm{mol} \mathrm{L}^{-1}$ of phosphate, and notably lower in the second two, especially for nitrate $\left(<1 \mu \mathrm{mol} \mathrm{L}^{-1}\right)$.

\section{Microbial Carbon Stocks and Fluxes}

In general, standing stocks and metabolic rates at ambient temperatures were higher in February and April than in August and October (Figure 1). Total chlorophyll $a$ values in the earlier months were higher than in the second part of the year (Figure 1A). Chlorophyll $a$ was dominated by larger cells in February (nano plus microplankton size fractions amounted to $74 \%$ of the total), while picophytoplankton prevailed in the rest of the experiments, contributing $50 \%$ in April, $46 \%$ in August and $58 \%$ in October to total chlorophyll $a$ concentration (Figure 1A).
The abundance of Live bacteria was relatively high in the four experiments, with a mean value of $1.15 \pm 0.06 \times 10^{6}$ cells $\mathrm{mL}^{-1}$, similar to the sum of th HNA and LNA fractions, but these subgroups showed opposite abundance patterns (Figure 1B). In consequence, their relative contribution to total numbers varied substantially with time, with HNA cells clearly dominating in February $(73 \%)$ and progressively being overtaken by LNA cells, until reaching a minimum 30\% contribution in October.

Ambient total primary production (TPP) decreased threefold from February and April (65.7 and $58.0 \mu \mathrm{g} \mathrm{C} \mathrm{L}^{-1} \mathrm{~d}^{-1}$, respectively) to the late summer-early fall values, with a minimum of $13.9 \mu \mathrm{g} \mathrm{C} \mathrm{L}^{-1} \mathrm{~d}^{-1}$ in August (Figure 1C). TPP followed the same pattern than phytoplankton biomass using total chlorophyll $a$. Dissolved primary production (DPP) was maximum in February (11.6 $\left.\mathrm{g} \mathrm{C} \mathrm{L}^{-1} \mathrm{~d}^{-1}\right)$ and minimum in October (3.2 $\mu \mathrm{g} \mathrm{C} \mathrm{L} \mathrm{L}^{-1} \mathrm{~d}^{-1}$; Figure 1C). The percent extracellular release (PER) was below $20 \%$ except in August, where TPP was almost evenly distributed among PPP and DPP (PER $=47 \%)$. 
Table 2. Relationship Between Heterotrophic and Autotrophic Fluxes

\begin{tabular}{lrrrrr}
\hline & BP/PPP & BP/TPP & BCD/TPP & DPP/BCD & NCP \\
\hline February & $2.0 \pm 0.1$ & $1.5 \pm 0.1$ & $35 \pm 0.1$ & $51 \pm 0.1$ & $29 \pm 5.8$ \\
April & $9.5 \pm 1.2$ & $8.7 \pm 1.1$ & $60 \pm 1.0$ & $14 \pm 0.9$ & $-29 \pm 12$ \\
August & $30 \pm 4.8$ & $15 \pm 1.6$ & $66 \pm 0.9$ & $70 \pm 6.3$ & $-15 \pm 1.6$ \\
October & $2.6 \pm 0.2$ & $2.2 \pm 0.2$ & $16 \pm 3.1$ & $90 \pm 20$ & $10 \pm 0.2$ \\
Mean & $11 \pm 6.5$ & $6.9 \pm 3.2$ & $44 \pm 11$ & $56 \pm 16$ & $-1.3 \pm 13$
\end{tabular}

Data from the initial time of sampling of each experiment. Values represent mean $\pm S E$, ratios are expressed as percentages, and NCP $=T P P-T R\left(\mu g\right.$ Carbon $L^{-1}$ day $\left.{ }^{-1}\right)$.

Bacterial production (BP) ranged from 0.6 to $4.9 \mu \mathrm{g} \mathrm{C} \mathrm{L}^{-1} \mathrm{~d}^{-1}$ (Figure 1D) and represented on average a low percentage of TPP and PPP, with a mean BP/TPP ratio of $6.9 \pm 3.2 \%$ and a $\mathrm{BP} / \mathrm{PPP}$ ratio of $11 \pm 6.5 \%$ (Table 2 ). Bacterial respiration (BR) (Figure 1D, E) was on average $15.7 \pm 6.2 \mu \mathrm{g} \mathrm{C} \mathrm{L}^{-1} \mathrm{~d}^{-1}$. Its contribution to TR or $\%$ BR was maximum in February (55\%) and minimum in October $(23 \%)$, with an average of $35 \pm 7 \%$. Bacterial carbon demand $(\mathrm{BCD}$, that is, the sum of $\mathrm{BP}$ and $\mathrm{BR}$ ) ranged one order of magnitude $\left(4.2-34.5 \mu \mathrm{g} \mathrm{C} \mathrm{L}^{-1} \mathrm{~d}^{-1}\right)$ and most of the carbon taken up was respired (Figure 1D). Consequently, bacterial growth efficiency (BGE) was low $(4-22 \%)$, reaching its highest value in August, coincident with the peak in PER. BCD was always lower than TPP but always higher than DPP (compare Figure 1C, D), with DPP representing between 14 and $90 \%$ of BCD (Table 2), suggesting the existence of other sources of DOC, additional to phytoplankton, to meet bacterial needs of carbon.

Bacterial respiration values estimated with the in vivo ETS method were further compared to modeled estimations available from the literature (Robinson 2008, Supplementary material Figure S2 and Table S1). Probably affected by the small number of samples, none of these estimates captured the variability shown in Figure 1D, E, with the estimation of Robinson (2008) overall better matching our measurements. The model of del Giorgio and Cole (2000) overestimated all our BR values. The model developed by López-Urrutia and Morán (2007), based on bacterial abundance and the temperature dependence of metabolism, captured well the first two experiments, but overestimated the last two. The opposite happened with the model of Rivkin and Legendre (2001), based on a negative relationship between bacterial growth efficiency and temperature, which captured well the last two experiments but underestimated the first two. Bacterial cell size was not considered as a predictor variable in any of these models but showed a positive correlation with ambient BR (Pearson $r=0.71 p=0.01, n=12$ ).
Total respiration (TR) ranged from 15.8 to $84.2 \mu \mathrm{g} \mathrm{C} \mathrm{L}^{-1} \mathrm{~d}^{-1}$ (Figure 1E) and exceeded TPP in April and August, resulting in negative net community production $(\mathrm{NCP}=\mathrm{TPP}-\mathrm{TR}, \quad$ Table 2$)$ values in these months and $<1$ TPP/TR ratios.

\section{Temperature Effects on the Microbial Carbon Flux}

The results of the GAMM analyses on the selected rates for each of the four experiments are shown in Figure 2. Experimental warming $\left(+2\right.$ and $\left.+4^{\circ} \mathrm{C}\right)$ did not produce a homogeneous effect across all rates and sampling months, with February and October as the months in which temperature had significant effects on more variables. Moreover, most effects were observed between the in situ and the $+4^{\circ} \mathrm{C}$ treatment. When significant, warming generally produced increases in the heterotrophic and autotrophic processes of the planktonic microbial community, except in October, when TPP and PPP were lower in the warmer incubations than in the in situ treatment. PPP increased with warming in February and DPP in April and October. PER consistently increased in all experiments with increasing temperature except in February. All heterotrophic processes tended also to increase with warming, except for BR, which was not affected by temperature. BP showed significant increases in February and October. Respiration of the organisms larger than $0.8 \mu \mathrm{m}$ (that is, virtually all organisms except bacteria) increased in February, August and October, as well as TR.

The averaged NCP for the 3-day incubation of the in situ temperature treatment was positive in February, indicating that the fixed carbon exceeded the respired carbon by $128 \pm 17 \mu \mathrm{g} \mathrm{C} \mathrm{L}^{-1} \mathrm{~d}^{-1}$. During April, August and October, TPP was lower than TR in the in situ incubations result ing in negative NCP $(-89 \pm 17,-32 \pm 4$, $-25 \pm 6 \mu \mathrm{g} \mathrm{C} \mathrm{L}^{-1} \mathrm{~d}^{-1}$ ) (Figure 3). With warming, we observed an increase in heterotrophy in August and October, with lower average NCP values in the $+4^{\circ} \mathrm{C}$ treatment compared to the values of the 

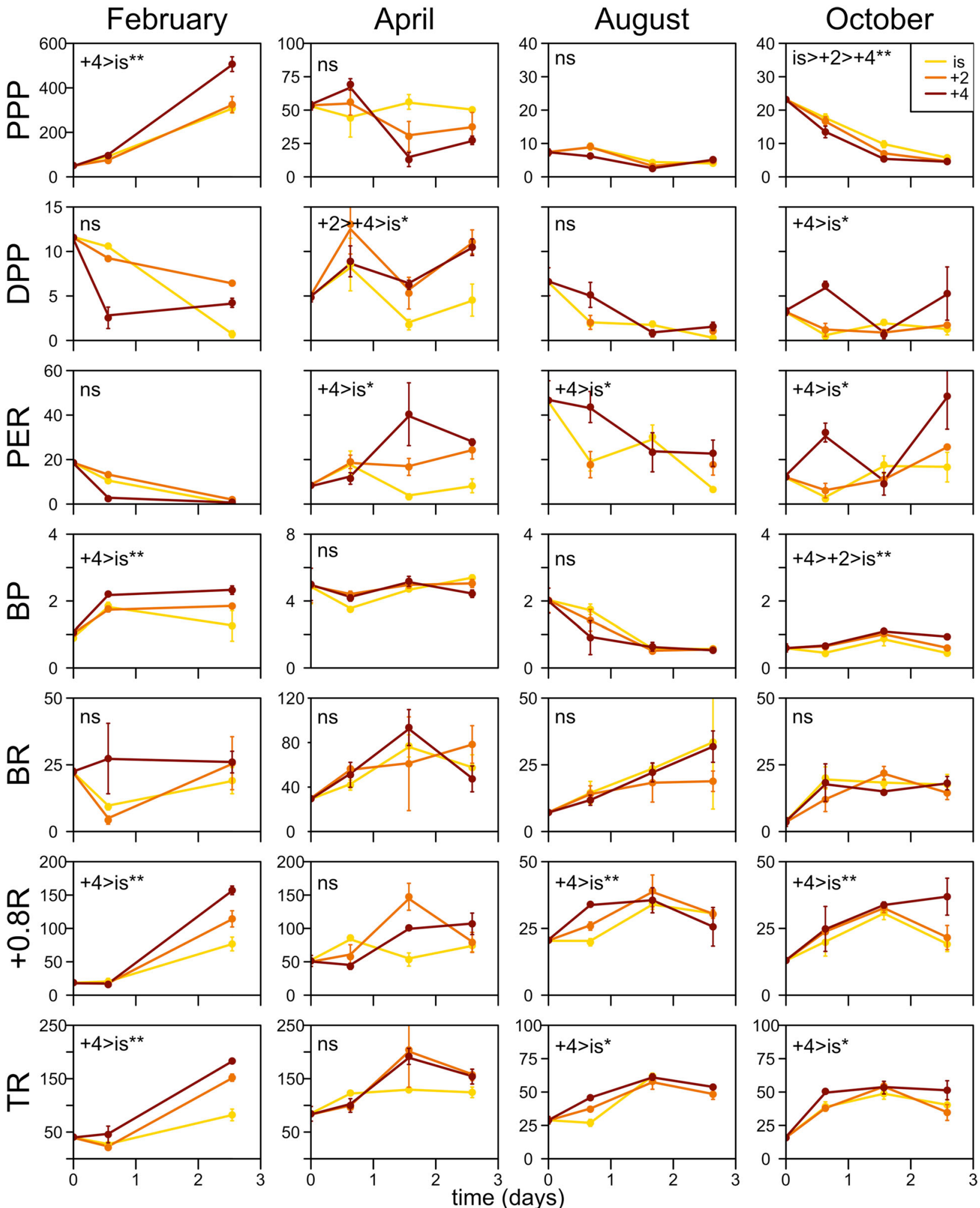

Figure 2. Daily evolution of carbon flux rates at each period and experimental warming treatment. All rates are expressed in $\mu \mathrm{g} \mathrm{C} \mathrm{L}^{-1} \mathrm{day}^{-1}$ except for PER (in \%). Annotations represent the significance level $(* *<0.01$; $* 0.05$ ) or nonsignificant (ns) effects detected by GAMM analysis between the different temperature treatments for the 3-day incubations. Note that $y$-axes vary between variables and periods. 


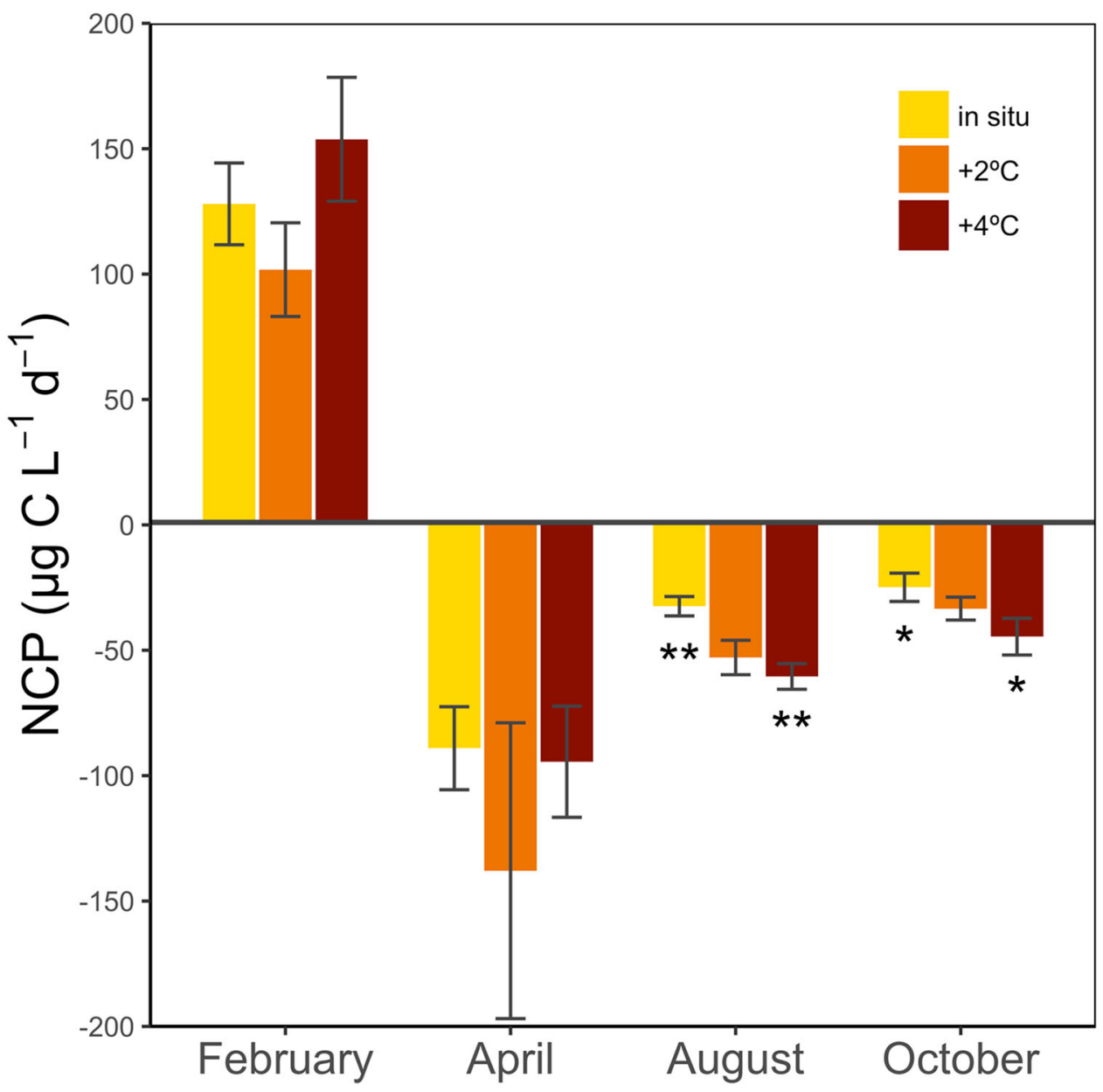

Figure 3. Net community production $(\mathrm{NCP}=\mathrm{TPP}-\mathrm{TR})$ averaged over the 3-day incubations in each of the four experiments. Annotations represent the significance level of effects detected with an ANOVA test between temperature treatments $\left({ }^{* *} p<0.01 ; * p<0.05\right)$.

in situ temperature treatment and no differences for $+2{ }^{\circ} \mathrm{C}$ treatment (ANOVA, $p<0.05, n=9$ ). These differences in the NCP values of in situ and $+4^{\circ} \mathrm{C}$ resulted in a net deficit of 28 and $20 \mu \mathrm{g} \mathrm{C} \mathrm{L}^{-1}$ $\mathrm{d}^{-1}$, respectively, for August and October. Consequently, the net TPP/TR ratio also decreased by 39.2 and $33.7 \%$, in these months compared to the in situ treatment.

\section{Discussion}

Microbial plankton carbon fluxes and their response to short-term experimental warming were simultaneously and comprehensively assessed at a coastal temperate ecosystem. The timing of the experiments was selected to represent the characteristic and highly predictable seasonal variability of temperate regions, in order to evaluate which periods or regimes may be more susceptible to warming. We succeeded in acquiring four very different scenarios regarding physicochemical (Table 1) and biological properties (Figure 1) as discussed below.

\section{Ambient Carbon Flux Variables and Interactions}

Ambient primary and bacterial production rates fit well within previous measurements at the study site (Morán 2007; Morán and Calvo-Díaz 2009; Franco-Vidal and Morán 2011; Morán and Scharek 2015), as well as values reported for other North Atlantic coastal ecosystems (Ducklow and others 2002; Fouilland and Mostajir 2010). However, February exhibited notably higher PPP values compared with 2003 (Morán and Scharek 2015), probably indicating the initial stages of a phytoplankton bloom. DPP, a generally overseen yet important contributor to total primary production rates (Morán and others 2002), represented almost half of TPP during summer (Figure 1C). 
Ambient BR values (mean $15.7 \pm 6.2 \mu \mathrm{g} \mathrm{C} \mathrm{L} \mathrm{L}^{-1}$ $\mathrm{d}^{-1}$ ) were similar to those reported at nearby sites by González and others (2003) using the Winkler method in summer and by Martínez-García and others $(2013 a, b)$ in summer and winter using the in vivo ETS method. Somewhat unexpectedly, it was not the bacteria but the larger planktonic organisms that had the highest contribution to total respiration. Consequently, the mean contribution of bacteria to total respiration ( $35 \pm 7 \%$ Figure $1 E$ ) was lower than the value proposed by Robinson (2008) from a global compilation (45\%) and much lower than in earlier studies (for example, up to $90 \%$ in Rivkin and Legendre 2001). However, it was similar to the $30 \%$ estimated by ArangurenGassis and others (2012) using the same methodology. These authors have proposed that global databases may have overestimated BR by using methods that require pre-filtration of the samples through small pore sizes, potentially breaking cells, making DOM available for bacteria and increasing their respiration rates during the incubation times. Accurate knowledge of bacterial respiration is not trivial but necessary to close the microbial carbon budget (Jahnke and Craven 1995; Gasol and others 2008). However, there is still an incomplete understanding of BR regulation, aggravated by its underrepresentation in global databases compared to BP (Robinson 2008). However, efforts have been made to try and estimate bacterial respiration from other routine, more easily measurable variables. Some of these models (Table S1) were compared with our empirical in vivo ETS data (Figure S2), which lay between the model of Rivkin and Legendre (2001) and the model of Robinson (2008). The model of López-Urrutia and Morán (2007), based on the metabolic theory of ecology predictions, tended to overestimate BR in summer and fall, assuming an exponential increase of BR with temperature. BR was lowest during these warmest months, indicating that other factors might also determine respiration at our site, for example cell size, which was positively related to BR. Organism size has proven to be a fundamental trait in metabolism (Brown and others 2004), and particularly for microbes, respiration has been shown to increase superlinearly with biovolume (García and others 2015). From Figure S2 it seems clear that the regulation of BR is still far from being completely understood and that estimating BR from models can result in large errors.

Similarly to our observation of the low contribution of heterotrophic bacteria to total respiration, we found that BP also represented a small amount of TPP (Table 2) and was not tightly coupled to phytoplanktonic activity. Considering BCD/DPP (Morán and others 2002), more sources other than DOC freshly produced by phytoplankton were always necessary to meet bacterial needs. However, under stratification (August and October), DPP accounted for a significant fraction of BCD (70 and $90 \%$, respectively), in accordance with the view that DPP is seemingly lower than BCD in most marine regions (Morán and others 2002; Fouilland and Mostajir 2010), except in oligotrophic waters or areas without allochthonous inputs (Morán and others 2002). BCD was mainly driven by BR (Figure $1 \mathrm{D})$, and therefore, BGE at in situ conditions (mean $13.7 \% \pm 1.4$ ) was also in the lower range of typical ocean values (10-30\%, del Giorgio and Cole 2000; Ducklow 2000; Alonso-Sáez and others 2007; Kirchman and others 2009), although values $<10 \%$ are not uncommon (González and others 2003; López-Urrutia and Morán 2007), indicating that most carbon consumed by heterotrophic bacteria was respired as $\mathrm{CO}_{2}$.

The metabolic balance clearly differed between the sampling periods, with positive ambient NCP in February and October and negative in April and August (Table 2). The temporal dynamics of net autotrophy and heterotrophy matched the observations made at a site located $50 \mathrm{~km}$ eastward (Serret and others 1999). Their analysis of a complete annual cycle of oxygen production and consumption suggests that transitions from net autotrophy to net heterotrophy (with an overall balanced situation, as suggested also by our dataset) are a persistent feature in the southern Bay of Biscay.

\section{Warming Effects on Microbial Carbon Fluxes}

The major aim of this study was to compare the effect of short-term moderate warming on carbon fluxes through planktonic microbes considering the seasonal shift between meso-/eutrophic to oligotrophic conditions (summarized by the change in chlorophyll $a$ from $1-3$ to $<0.5 \mu \mathrm{g} \mathrm{L}^{-1}$ ). Keeping in mind that short incubations may not represent adequately long-term warming responses, this study is highly relevant since coastal areas are the most productive oceanic regions (Chen and Borges 2009; Bauer and others 2013), as well as the most susceptible to warming, particularly in the Northern Hemisphere (Rhein and others 2013).

Because the metabolism of both autotrophic and heterotrophic plankton is largely dependent on temperature (Lomas and others 2002, López-Urrutia and others 2006), in the absence of nutrient 
limitation (López-Urrutia and Morán 2007) all rates were expected to increase with warming, albeit with different temperature dependences. However, experimental warming did not produce a systematic increase and the responses in each month were also different. Interestingly, the differences detected between the in situ and $+4^{\circ} \mathrm{C}$ treatment were more frequent (that is, affected $4-5$ variables) in the February and October experiments. The experimental warming of +2 and $+4^{\circ} \mathrm{C}$ was realistic in terms of the most recent IPCC projections (Collins and others 2013). However, the seasonal cycle of temperature in the Bay of Biscay is wider $\left(>10^{\circ} \mathrm{C}\right)$, so some responses might have been difficult to identify considering that the metabolic machineries of most planktonic organisms are flexible and adapted to natural temperature ranges (Hoppe and others 2008). On the other hand, seasonal warming does not take place as fast as in our short-term experimental incubations, so lack of time for acclimation may be another explanation for the absence of response of some variables. In addition, the statistical treatment is quite conservative and would have been benefited from a larger sample size.

The responses to warming of autotrophic plankton varied according to the seasonal scenario (Figure 2) and were driven mainly by changes in PPP. Only in February, phytoplankton increased their metabolism when exposed to higher temperature, indicating that in the rest of experiments (mainly, August and October), nutrient limitation had a stronger effect than temperature (Lewandowska and others 2014) and prevented the expected rise. Even in April, during the spring bloom, $N$ and $P$ values were high but other nutrients may have already become limiting (for example, Si for diatoms, the dominant phytoplankton group forming spring blooms at the site: Morán and Scharek 2015). Interestingly, although DPP did not show a consistent response, PER was significantly higher with warming in all experiments but in February. PER increases were also observed in short-term (6 h) warming incubations in the Southern Ocean (Morán and others 2006) and in mesocosm experiments in the Baltic Sea (Engel and others 2011). The increase in PER with warming may be a mechanism to free excess photosynthetic products under adverse conditions such as low inorganic nutrient availability or thermal stress (Zlotnik and Dubinsky 1989; Teira and others 2001; Schartau and others 2007; VilaReixach and others 2012). Although DPP is an important source of organic matter for bacteria, the increase in PER was not followed by increases in BP except in October, either because DPP compounds were not labile for bacterial processing (Engel and others 2011), the assimilation of DOM was delayed or there was concurrent inorganic nutrient limitation ( $\mathrm{O}^{\prime}$ Connor and others 2009). Increased BP in response to PER increases with warming was not observed in the Southern Ocean in similar experiments except under very oligotrophic conditions (Morán and others 2006), indicating that the response of BP to DPP and warming is not straightforward. Actually, BP increased with warming in February, not related to PER changes, suggesting that under substrate availability, the key environmental driver of BP was temperature, as previously suggested (Moran and others 2010; Calvo-Díaz and others 2014).

Heterotrophic processes are expected to be more responsive to temperature (Allen and others 2005; López-Urrutia and others 2006). In addition to the aforementioned changes in BP, we also observed increases in respiration rates, both in the total and in the large fraction, with warming in February, August and October. However, and contrary to expected, we did not find a response of BR to temperature. Some of our samples showed high variability between replicates, which may have prevented the detection of statistically significant differences, especially for BR data. Wohlers and others (2009) measured BR and DOC in mesocosm warming experiments in the Baltic and did not see increases in respiration in the smallerthan-3 $\mu \mathrm{m}$ planktonic fraction, proposing that freshly produced organic carbon was not immediately respired by bacteria. Interestingly, our BR was not coupled to PER increases, concurring with Wohlers and others (2009) and Engel and others (2011) that increases in phytoplankton-derived DOM in the warmer treatments was not readily available for bacteria, perhaps because of poor quality. Engel and others (2011) suggest that under warming and nutrient depletion, phytoplankton increase the exudation of less labile, high molecular weight polysaccharides, which accumulate in the environment. While Kritzberg and others (2010) did see increases of BR in warming experiments in the Arctic, they considered BR as the fraction less than $10 \mu \mathrm{m}$, therefore including a substantial amount of planktonic organisms other than bacteria. It is also possible that larger cells and particle-associated cells, typically more active (Gasol and others 2008), were retained on the $0.8 \mu \mathrm{m}$ filter, which could have underestimated our BR, especially in April, when bacterial cells were larger. Despite the observed changes in BP in February and October, we did not detect changes 
in BGE (or BCD) with warming in any of our experiments, contrary to the common assumption that BGE decreases with temperature (Rivkin and Legendre 2001).

Combining autotrophic and heterotrophic responses, we found that in August and October the production-to-respiration ratio in our ecosystem (TPP/TR) decreased between the in situ and $+4^{\circ} \mathrm{C}$ treatment, and accordingly, the net community production also became more negative (Figure 3). Despite the customary importance assigned to the bacterial fraction, their response to experimental warming was not very relevant, whereas warming enhanced the net heterotrophy mainly due to increases in the respiration of large planktonic organisms (mostly protistan grazers and phytoplankton) and to decreases in primary production under the oligotrophic conditions found in August and October. This is in accordance with the idea that protistan and metazoan grazing has a major effect on planktonic microbes, accounting for $60 \%$ of phytoplankton mortality rates in coastal areas and respiring 35$59 \%$ of primary production (Calbet and Landry 2004). With future warming, our study shows that the already substantial respiration rates of larger organisms (including phytoplankton and protistan and metazoan grazers) increase more than biomass production especially under oligotrophic conditions, driving the system toward a more heterotrophic metabolic state, as suggested by López-Urrutia and others (2006).

In general, the variability found in our experiments corroborates that responses to warming in different oceanic regions will be far from homogeneous and difficult to predict (Morán and others 2006; Vázquez-Domínguez and others 2007; O'Connor and others 2009; Wohlers and others 2009; Kritzberg and others 2010; Pires and others 2014), because very similar initial conditions of temperature and nutrient concentrations in the experiments of February-April and in those of August-October, rendered very different outcomes. However, our experiments confirm the important interaction between temperature and substrates in evaluating changes in microbial plankton processes $\left(\mathrm{O}^{\prime}\right.$ Connor and others 2009; Kritzberg and others 2010). We suggest (Figure 3 ) that more productive regions and periods (such as February in our experiments) would likely remain net autotrophic or close to metabolic balance, while in oligotrophic conditions (met here in August and October) coastal ecosystems may become more heterotrophic with warming.

\section{ACKNOWLEDGEMENTS}

We would like to thank the Spanish Institute of Oceanography (IEO) for our participation in the monthly time series cruises off Gijón/Xixón of the RADIALES project. As well, we would like to thank all the staff of the R/V "Ramón Margalef" and R/V "Ángeles Alvariño," for their assistance in collecting samples. We are especially grateful to Virginia Polonio and Lucie Buttay for their help during the experiments of August and October. This work was supported by the Gobierno vasco, through a Ph.D. scholarship to N. Arandia-Gorostidi and the Spanish Ministry of Economy and Competitiveness (MINECO) through funding of the time series project RADIALES of the IEO, the COMITE (Coastal Ocean Microbial plankton and Temperature) project (CTM-2010-15840), including a PhD scholarship (BES-2011-048573) to TM HueteStauffer, and a Postdoctoral Fellow to A. Calvo-Díaz (JCI-2012-14680).

\section{OPEN ACCESS}

This article is distributed under the terms of the Creative Commons Attribution 4.0 International License (http://creativecommons.org/licenses/by/ 4.0/), which permits unrestricted use, distribution, and reproduction in any medium, provided you give appropriate credit to the original author(s) and the source, provide a link to the Creative Commons license, and indicate if changes were made.

\section{REFERENCES}

Allen AP, Gillooly JF, Brown JH. 2005. Linking the global carbon cycle to individual metabolism. Funct Ecol 19:202-13.

Alonso-Sáez L, Arístegui J, Pinhassi J, Gómez-Consarnau L, González JM, Vaqué D, Agustí S, Gasol JM. 2007. Bacterial assemblage structure and carbon metabolism along a productivity gradient in the NE Atlantic Ocean. Aquat Microb Ecol 46:43-53.

Aranguren-Gassis M, Teira E, Serret P, Martínez-García S, Fernández E. 2012. Potential overestimation of bacterial respiration rates in oligotrophic plankton communities. Mar Ecol Prog Ser 453:1-10.

Azam F. 1998. Microbial control of oceanic carbon flux: the plot thickens. Science 280:694-6.

Azam F, Malfatti F. 2007. Microbial structuring of marine ecosystems. Nat Rev Microbiol 5:782-91.

Bauer JE, Cai W-J, Raymond PA, Bianchi TS, Hopkinson CS, Regnier PAG. 2013. The changing carbon cycle of the coastal ocean. Nature 504:61-70.

Behrenfeld M. 2011. Biology: uncertain future for ocean algae. Nat Clim Change 1:33-4.

Behrenfeld MJ, O'Malley RT, Siegel DA, McClain CR, Sarmiento JL, Feldman GC, Milligan AJ, Falkowski PG, Letelier RM, Boss ES. 2006. Climate-driven trends in contemporary ocean productivity. Nature 444:752-5. 
Bjørnsen PK, Kuparinen J. 1991. Determination of bacterioplankton biomass, net production and growth efficiency in the Southern Ocean. Mar Ecol Prog Ser 71:185-94.

Brown JH, Gillooly JF, Allen AP, Savage VM, West GB. 2004. Toward a metabolic theory of ecology. Ecology 85:1771-89.

Calbet A, Landry MR. 2004. Phytoplankton growth, microzooplankton grazing, and carbon cycling in marine systems. Limnol Oceanogr 49:51-7.

Calvo-Díaz A, Díaz-Pérez L, Suárez LA, Morán XAG, Teira E, Marañón E. 2011. Decrease in the autotrophic-to-heterotrophic biomass ratio of picoplankton in oligotrophic marine waters due to bottle enclosure. Appl Environ Microbiol 77:5739-46.

Calvo-Díaz A, Franco-Vidal L, Morán XAG. 2014. Annual cycles of bacterioplankton biomass and production suggest a general switch between temperature and resource control in temperate coastal ecosystems. J Plankton Res 36:859-65.

Calvo-Díaz A, Morán XAG. 2006. Seasonal dynamics of picoplankton in shelf waters of the southern Bay of Biscay. Aquat Microb Ecol 42:159-74.

Calvo-Díaz A, Morán XAG. 2009. Empirical leucine-to-carbon conversion factors for estimating heterotrophic bacterial production: seasonality and predictability in a temperate coastal ecosystem. Appl Environ Microbiol 75:3216-21.

Chen C-TA, Borges AV. 2009. Reconciling opposing views on carbon cycling in the coastal ocean: continental shelves as sinks and near-shore ecosystems as sources of atmospheric $\mathrm{CO}_{2}$. Deep Sea Res Part II 56:578-90.

Collins M, Knutti R, Arblaster J, Dufresne J, Fichefet T, Friedlingstein P, Gao X, Gutowski W, Johns T, Krinner G, Shongwe M, Tebaldi C, Weaver A, Wehner M. 2013. Longterm climate change: projections, commitments and irreversibility. In: Stocker T, Qin D, Plattner G, Tignor M, Allen S, Boschung J, Nauels A, Xia Y, Bex V, Midgley P, Eds. Climate change 2013: the physical science basis. Contribution of working group I to the fifth assessment report of the intergovernmental panel on climate change. Cambridge: Cambridge University Press. p 1029-136.

del Giorgio PA, Cole JJ. 1998. Bacterial growth efficiency in natural aquatic systems. Annu Rev Ecol Syst 29:503-41.

del Giorgio PA, Cole JJ. 2000. Bacterial energetics and growth efficiency. In: Kirchman DL, Ed. Microbial ecology of the oceans. New York: Wiley-Liss. Inc. p 289-325.

de Boyer Montégut C, Madec G, Fischer AS, Lazar A, Iudicone D. 2004. Mixed layer depth over the global ocean: an examination of profile data and a profile-based climatology. J Geophys Res 109:1-20.

Doney SC. 2006. Oceanography: plankton in a warmer world. Nature 444:695-6.

Dring M, Jewson D. 1982. What does ${ }^{14} \mathrm{C}$ uptake by phytoplankton really measure? A theoretical modelling approach. Proc R Soc Lond B 214:351-68.

Ducklow H. 2000. Bacterial production and biomass in the Oceans. In: Kirchman DL, Ed. Microbial ecology of the oceans. New York: Wiley-Liss. Inc. p 85-120.

Ducklow HW, Doney SC. 2013. What is the metabolic state of the oligotrophic ocean? A debate. Ann Rev Mar Sci 5:525-33.

Ducklow HW, Kirchman DL, Anderson TR. 2002. The magnitude of spring bacterial production in the North Atlantic Ocean. Limnol Oceanogr 47:1684-93.

Ducklow HW, Morán XAG, Murray AE. 2010. Bacteria in the greenhouse: marine microbes and climate change. In: Mitchell
R, Gu J-D, Eds. Environmental microbiology. 2nd edn. Hoboken: Wiley. p 1-31.

Engel A, Händel N, Wohlers J, Lunau M, Grossart H-P, Sommer U, Riebesell U. 2011. Effects of sea surface warming on the production and composition of dissolved organic matter during phytoplankton blooms: results from a mesocosm study. J Plankton Res 33:357-72.

Falcioni T, Papa S, Gasol JM. 2008. Evaluating the flow-cytometric nucleic acid double-staining protocol in realistic situations of planktonic bacterial death. Appl Environ Microbiol 74:1767-79.

Field CB, Behrenfeld MJ, Randerson JT, Falkowski P. 1998. primary production of the biosphere: integrating terrestrial and oceanic components. Science 281:237-40.

Fouilland E, Mostajir B. 2010. Revisited phytoplanktonic carbon dependency of heterotrophic bacteria in freshwaters, transitional, coastal and oceanic waters. FEMS Microbiol Ecol 73:419-29.

Franco-Vidal L, Morán XAG. 2011. Relationships between coastal bacterioplankton growth rates and biomass production: comparison of leucine and thymidine uptake with singlecell physiological characteristics. Microb Ecol 61:328-41.

Fuhrman JA. 2009. Microbial community structure and its functional implications. Nature 459:193-9.

García FC, García-Martín EE, Taboada FG, Sal S, Serret P, Lópezurrutia Á. 2015. The allometry of the smallest: superlinear scaling of microbial metabolic rates in the Atlantic Ocean. ISME J 10:1029-36.

Gasol JM, Pinhassi J, Alonso-Sáez L, Ducklow H, Herndl GJ, Koblizek M, Labrenz M, Luo Y, Morán XAG, Reinthaler T, Simon M. 2008. Towards a better understanding of microbial carbon flux in the sea. Aquat Microb Ecol 53:21-38.

Gillooly JF, Brown JH, West GB, Savage VM, Charnov EL. 2001. Effects of size and temperature on metabolic rate. Science 293:2248-51.

González N, Anadón R, Viesca L. 2003. Carbon flux through the microbial community in a temperate sea during summer: role of bacterial metabolism. Aquat Microb Ecol 33:117-26.

González N, Gattuso J-P, Middleburg JJ. 2008. Oxygen production and carbon fixation in oligotrophic coastal bays and the relationship with gross and net primary production. Aquat Microb Ecol 52:119-30.

Grégori G, Citterio S, Ghiani A, Labra M, Sgorbati S, Brown S, Denis M. 2001. Resolution of viable and membrane-compromised bacteria in freshwater and marine waters based on analytical flow cytometry and nucleic acid double staining. Appl Environ Microbiol 67:4662-70.

Hoppe HG, Breithaupt P, Walther K, Koppe R, Bleck S, Sommer U, Jürgens K. 2008. Climate warming in winter affects the coupling between phytoplankton and bacteria during the spring bloom: a mesocosm study. Aquat Microb Ecol 51:10515.

Huete-Stauffer TM, Arandia-Gorostidi N, Díaz-Pérez L, Morán XAG. 2015. Temperature dependences of growth rates and carrying capacities of marine bacteria depart from metabolic theoretical predictions. FEMS Microbiol Ecol 91:fiv111.

Jahnke RA, Craven DB. 1995. Quantifying the role of heterotrophic bacteria in the carbon cycle: a need for respiration rate measurements'. Limnol Oceanogr 40:436-41.

Jorgensen BB. 2000. Bacteria and marine biogeochemistry. In: Schultz HD, Zabel M, Eds. Marine geochemistry. Berlin: Springer. p 173-207. 
Kirchman D, K'nees E, Hodson R. 1985. Leucine incorporation and its potential as a measure of protein synthesis by bacteria in natural aquatic systems. Appl Environ Microbiol 49:599607.

Kirchman DL, Morán XAG, Ducklow H. 2009. Microbial growth in the polar oceans-role of temperature and potential impact of climate change. Nat Rev Microbiol 7:451-9.

Kritzberg ES, Duarte CM, Wassmann P. 2010. Changes in Arctic marine bacterial carbon metabolism in response to increasing temperature. Polar Biol 33:1673-82.

Lewandowska AM, Boyce DG, Hofmann M, Matthiessen B, Sommer U, Worm B. 2014. Effects of sea surface warming on marine plankton. Ecol Lett 17:614-23.

Lomas MW, Glibert PM, Shiah FK, Smith EM. 2002. Microbial processes and temperature in Chesapeake Bay: current relationships and potential impacts of regional warming. Glob Change Biol 8:51-70.

López-Urrutia A, Morán XAG. 2007. Resource limitation of bacterial production distorts the temperature dependence of oceanic carbon cycling. Ecology 88:817-22. http://www.ncbi. nlm.nih.gov/pubmed/17536698

López-Urrutia A, San Martin E, Harris RP, Irigoien X. 2006. Scaling the metabolic balance of the oceans. Proc Natl Acad Sci USA 103:8739-44.

Marie D, Partensky F, Jacquet S, Vaulot D. 1997. Enumeration and cell cycle analysis of natural populations of marine picoplankton by flow cytometry using the nucleic acid stain SYBR Green I. Appl Environ Microbiol 63:186-93.

Marra J. 2002. Approaches to the measurement of plankton production. In: Williams PJLB, Thomas DN, Reynolds CS, Eds. Phytoplankton productivity: carbon assimilation in marine and freshwater ecosystems. Oxford: Blackwell. p 78-108.

Marra J. 2009. Net and gross productivity: weighing in with ${ }^{14} \mathrm{C}$. Aquat Microb Ecol 56:123-31.

Martínez-García S, Fernández E, Aranguren-Gassis M, Teira E. 2009. In vivo electron transport system activity: a method to estimate respiration in natural marine microbial planktonic communities. Limnol Oceanogr Methods 7:459-69.

Martínez-García S, Fernández E, Calvo-Díaz A, Cermeño P, Marañón E, Morán XAG, Teira E. 2013a. Differential response of microbial plankton to nutrient inputs in oligotrophic versus mesotrophic waters of the North Atlantic. Mar Biol Res 9:3741.

Martínez-García S, Fernández E, Del Valle DA, Karl DM, Teira E. 2013b. Experimental assessment of marine bacterial respiration. Aquat Microb Ecol 70:189-205.

Monterey G, Levitus S. 1997. Seasonal variability of mixed layer depth for the world ocean. In: NOAA Atlas NESDIS 14. Washington DC. p 100.

Morán XAG. 2007. Annual cycle of picophytoplankton photosynthesis and growth rates in a temperate coastal ecosystem: a major contribution to carbon fluxes. Aquat Microb Ecol 49:267-79.

Morán XAG, Calvo-Díaz A. 2009. Single-cell vs. bulk activity properties of coastal bacterioplankton over an annual cycle in a temperate ecosystem. FEMS Microbiol Ecol 67:43-56.

Morán XAG, Calvo-Díaz A, Ducklow HW. 2010. Total and phytoplankton mediated bottom-up control of bacterioplankton change with temperature in NE Atlantic shelf waters. Aquat Microb Ecol 58:229-39.

Morán XAG, Estrada M, Gasol JM, Pedrós-Alió C. 2002. Dissolved primary production and the strength of phytoplank- ton-bacterioplankton coupling in contrasting marine regions. Microb Ecol 44:217-23.

Morán XAG, Scharek R. 2015. Photosynthetic parameters and primary production, with focus on large phytoplankton, in a temperate mid-shelf ecosystem. Estuar Coast Shelf Sci 154:255-63.

Morán XAG, Sebastián M, Pedrós-Alió C, Estrada M. 2006. Response of Southern Ocean phytoplankton and bacterioplankton production to short-term experimental warming. Limnol Oceanogr 51:1791-800.

Morán XAG, Gasol JM, Pedrós-Alió C, Estrada M. 2001. Dissolved and particulate primary production and bacterial production in offshore Antarctic waters during austral summer: coupled or uncoupled? Mar Ecol Prog Ser 222:25-39.

Norland S. 1993. The relationship between biomass and volume of bacteria. In: Kemp PF, Sherr BF, Sherr EB, Cole JJ, Eds. Handbook of methods in aquatic microbial ecology. 1st edn. Boca Raton: Lewis Publishers. p 303-7.

O'Connor MI, Piehler MF, Leech DM, Anton A, Bruno JF. 2009. Warming and resource availability shift food web structure and metabolism. PLoS Biol 7:e1000178.

Pires APF, Guariento RD, Laque T, Esteves FA, Farjalla VF. 2014. The negative effects of temperature increase on bacterial respiration are independent of changes in community composition. Environ Microbiol Rep 6:131-5.

Pomeroy L, Wiebe W. 2001. Temperature and substrates as interactive limiting factors for marine heterotrophic bacteria. Aquat Microb Ecol 23:187-204.

Rhein M, Rintoul SR, Aoki S, Campos E, Chambers D, Feely RA, Gulev S, Johnson GC, Josey GC, Kostianoy A, Mauritzen C, Roemmich D, Talley LD, Wang F. 2013. Observations: ocean. In: Stocker TF, Qin D, Plattner G-K, Tignor M, Allen SK, Boschung J, Nauels A, Xia Y, Bex V, Midgley P, Eds. Climate change 2013: the physical science basis. Contribution of working group I to the fifth assessment report of the intergovernmental panel on climate change. Cambridge: Cambridge University Press. p 255-316.

Rivkin RB, Legendre L. 2001. Biogenic carbon cycling in the upper ocean: effects of microbial respiration. Science 291:2398-400.

Robinson C. 2008. Heterotrophic bacterial respiration. In: Kirchman DL, Ed. Microbial ecology of the oceans. 2nd edn. Hoboken: Wiley. p 299-334.

Sarmiento JL, Slater R, Barber R, Bopp L, Doney SC, Hirst AC, Kleypas J, Matear R, Mikolajewicz U, Monfray P, Soldatov V, Spall SA, Stouffer R. 2004. Response of ocean ecosystems to climate warming. Global Biogeochem Cycles 18:6-7.

Schartau M, Engel A, Thoms S, Völker C, Wolf-Gladrow D. 2007. Modelling carbon overconsumption and the formation of extracellular particulate organic carbon. Biogeosciences $4: 433-54$.

Serret P, Fernández E, Sostres J, Anadón R. 1999. Seasonal compensation of microbial production and respiration in a temperate sea. Mar Ecol Prog Ser 187:43-57.

Serret P, Robinson C, Fernández E, Teira E, Tilstone G. 2001. Latitudinal variation of the balance between plankton photosynthesis and respiration in the eastern Atlantic Ocean. Limnol Oceanogr 46:1642-52.

Smith DC, Azam F. 1992. A simple, economical method for measuring bacterial protein synthesis rates in seawater using tritiated-leucine. Mar Microb Food Webs 6:107-14. 
Stone R. 2010. The invisible hand behind a vast carbon reservoir. Science 328:1476.

Teira E, Pazo MJ, Serret P, Fernández E. 2001. Dissolved organic carbon production by microbial populations in the Atlantic Ocean. Limnol Oceanogr 46:1370-7.

Vázquez-Domínguez E, Vaqué D, Gasol JM. 2007. Ocean warming enhances respiration and carbon demand of coastal microbial plankton. Glob Change Biol 13:1327-34.

Vila-Reixach G, Gasol JM, Cardelús C, Vidal M. 2012. Seasonal dynamics and net production of dissolved organic carbon in an oligotrophic coastal environment. Mar Ecol Prog Ser 456:7-19.

West GB, Brown JH, Enquist BJ. 1999. The fourth dimension of life: fractal geometry and allometric scaling of organisms. Science 284:1677-9.

Wohlers J, Engel A, Zöllner E, Breithaupt P, Jürgens K, Hoppe H-G, Sommer U, Riebesell U. 2009. Changes in biogenic car- bon flow in response to sea surface warming. PNAS 106:706772.

Wood SN. 2004. Stable and efficient multiple smoothing parameter estimation for generalized additive models. J Am Stat Assoc 99:673-86.

Yvon-Durocher G, Caffrey JM, Cescatti A, Dossena M, del Giorgio P, Gasol JM, Montoya JM, Pumpanen J, Staehr PA, Trimmer M, Woodward G, Allen AP. 2012. Reconciling the temperature dependence of respiration across timescales and ecosystem types. Nature 487:472-6.

Zlotnik I, Dubinsky Z. 1989. The effect of light and temperature on DOC excretion by phytoplankton. Limnol Oceanogr 34:831-9.

Zuur AF, Ieno EN, Walker NJ, Saveliev AA, Smith GM. 2009. Chapter 5: Mixed effects modelling for nested data. In: Gail M, Krickeberg K, Samet J, Tsiatis A, Wong W, Eds. Mixed effects models and extensions in ecology with R. New York: Springer. 